\title{
15
}

\section{Education outlay, fiscal transfers and interregional funding equity: A county-level analysis of education finance in China}

\section{Ping Zhang, Zizhou Bu, Youqiang Wang and Yilin Hou}

\section{Introduction}

Equity in education finance has been a key policy and social issue since the mid-twentieth century. Governments worldwide have made great efforts to provide more equitable opportunities for education for their citizens as an investment in human capital. Local governments often shoulder the largest share of education costs, so, to address the issue of intraregional inequity resulting from local funding, subnational governments often redistribute resources collected from progressive taxes. In some countries, the central government also takes on some funding responsibility to address interregional inequity.

In the past three decades, against the background of high economic growth and rapid sociopolitical development, education finance in China has transitioned from a local government-only regime to a new regime that involves a combination of local, provincial and central government funding. This fast-tracked transition provides a good window for scholars to study the impact of the changing education finance regimes. Since reform of the country's central-local government tax-sharing system in 
1994 and income tax reform in 2002, transfer payments from higher levels of government (central and provincial) to lower levels (county) have been a critical policy tool to improve equity in the provision of basic education. Beginning in 2000, the central government stepped in (with requirements for provincial shares of funding), aiming to drastically reduce interregional disparity and improve equity as well as the overall quality of basic education throughout China's vast rural areas. For example, in 2001, the State Council issued the 'Decision on Basic Education Reform and Development' to establish a county-oriented rural compulsory education system and to shift responsibility for setting rural teacher salaries from the township to the county level. To promote compulsory education, there were also two waves of initiatives under the Poor Region Compulsory Education Program, in 1995-2000 and 2000-05.

This chapter examines the effects of these funding reforms on education funding equity in China, with a particular focus on intraprovincial equity and funding for rural communities. We will test the differential effects of the regime's transition on the equity of education finance, taking advantage of provincial-level data and a panel dataset of county-level jurisdictions across the country. We will control for local own-source revenue, transfers (total and by type), local economic conditions, local demographics, policy shocks, the urban-rural divide and the region (east, central and western China). The chapter contributes to the literature in several important ways. It will dissect the differential effects of local, provincial and central funding levels on intraprovince equity of overall education finance and provide evidence on how policy shocks in a fast-growing economy affect education provision in a transitioning system. The chapter will also shed light on how elements of fiscal federalism work in a unitary state system.

The chapter is organised as follows. The next section briefly reviews the relevant literature, while section three explains our concept of education funding equity and our modelling methodology in the context of China's current rapid socioeconomic transition. Section four presents and discusses the empirical results and the final section provides some concluding comments. 


\section{Literature review}

Adequacy, equity and efficiency are among the key issues in education finance. Research on education finance equity is targeted primarily towards examining whether education as a public good is provided equitably to students or whether schools and districts are funded equitably with sufficient resources to cover teachers, supplies and infrastructure for the equitable provision of education services to students. Equitable education investment across districts and groups helps to narrow future productivity gaps and achieve sustained growth, broader equity and access to decent living standards. As a public good, basic education is financed mainly through taxation and is mostly managed by government; thus, government shoulders the responsibility for resource equity as well as adequacy.

Measuring equity and setting equity standards present a research challenge. Berne and Stiefel (1994) explore conceptual, methodological and empirical issues in resource allocation at the intradistrict and school levels. They suggest that equity concepts can be applied at the school level; they also identify a series of methodological issues and include an empirical analysis of equity at the intradistrict and school levels in New York. Duncombe and Yinger (1998) show how to estimate comprehensive educational cost indexes that control for school district inefficiency, and include them in state aid formulas aimed at achieving equity. They simulate for New York the impact of several aid formulas on educational performance and evaluate them using several equity criteria. Murray et al. (1998) use variations across states over time to investigate the impact of reform on the distribution of school resources. Their results suggest that court-ordered finance reform reduced intrastate inequality in spending by 19 to 34 per cent. Successful litigation reduced inequality by requiring increased spending in the poorest districts while leaving spending in the richest districts unchanged, thereby increasing aggregate spending on education. Rubenstein et al. (2008) use an 11-year panel dataset containing information on revenue, expenditure and demographics for every school district in the United States; they examine the effects of state-adopted school accountability systems on the adequacy and equity of school resources. They find little relationship between state implementation of accountability systems and changes in school finance equity, although they do find evidence that states in which courts overturned the school finance system during the decade of their study exhibited significant equity improvements. Additionally, 
while implementation of accountability per se does not appear to be linked to changes in resource adequacy, states that implemented strong accountability systems did experience improvements.

The type of system used for financing and providing education can have a number of practical implications. Baicker and Gordon (2006) find that, in the United States, states finance the required increase in education spending in part by reducing their aid for other programs. Thus, while court-ordered school finance equalisations do increase total state aid to localities for education, they do so at the expense of drawing state intergovernmental aid away from programs such as public welfare, health, hospitals and general services. These results have significant implications for redistribution policy in a federal system - both across programs and across localities. Besley and Coate (2003) suggest that modelling the details of political decision-making is important for understanding the trade-off between centralisation and decentralisation. They show why even relatively homogeneous polities may face a cost from centralisation whether or not the (central) legislature is cooperative. This insight is underpinned by the way in which different interests play out in the legislature in a system of pooled finances. Moreover, even with a cooperative legislature, the familiar presumption that centralisation facilitates higher spillovers (and greater equity in resource distribution) does not always emerge. Andrews et al. (2002) define the factors affecting economies of size, updating the literature from 1980. Cost function studies suggest that sizeable potential savings in instructional and administrative costs may exist by moving from a very small district (500 or fewer pupils) to a district with $2,000-4,000$ pupils. The findings from production function studies of schools are less consistent, but there is some evidence that moderately sized elementary schools (300-500 students) and high schools (600-900 students) may optimally balance economies of size with the potential negative effects of large schools. Program evaluation research on school consolidation is limited, however, and the potential diseconomies of size in large central city school districts have yet to be fully explored. The optimal size of schools is an important factor in education resourcing, including the achievement of efficient and equitable resource distribution. 


\section{The case of China}

Since the early 1980s, the financing of basic education in China has moved rapidly away from a centralised system with a narrow revenue base to a decentralised system with a diversified revenue base. This chapter provides a critical assessment of the impacts of the financial reform of basic education in China, focusing on issues of structure, resource mobilisation, inequality and inefficiency. It concludes that, while the reform has been successful in achieving the objectives of structural change and mobilisation of additional government and non-government resources, the current system is marked by notable weaknesses in terms of glaring inequalities and significant inefficiencies. Further improvements of the financing system require interventions both inside and outside the education sector.

The Chinese Government has long realised the key role of basic education in the country's strategic development and hence made it a statutory requirement to guarantee adequate input into education; the revised Law on Compulsory Education (2006, revised version) stipulates that the state (i.e. government at all levels) bears responsibility for adequately funding education through its annual budgets.

Since 2000, the central government, with more revenue from large central taxes, began to invest heavily in education by granting increasingly large annual transfers specifically designated for teacher salaries, school construction, subsidies for student meals and supplies, as well as boarding (dormitory) costs, in poor, rural and remote (mountain and pastoral) areas. In the meantime, provincial governments, at the direction of the centre, have also started providing more funding than previously for education. These fiscal transfers have provided an avenue for funding equity that has become a new priority, and education funding is now provided through a new, more centralised scheme.

Wang (2004) provides a discussion of county-level budgeting in China. Based on field studies in three poverty-stricken counties in north-western China, she argues that the existing institutional arrangement for budget formulation does not enable wide participation in the budget process, and the separation of citizen demands from the spending priorities of county governments has contributed to a lack of social equity in the provision of public services. The most serious problem is that the needs of the poorest and thus the most needy citizens are overlooked. Because of 
this separation, citizens have to be self-reliant in solving problems outside the purview of government budgeting. Wang (2004) argues that the elimination of extra-budgetary funds as a key measure in financial reform in rural areas is not the solution to the problem. The spending priorities of county governments have to be changed and the political configuration behind such priorities has to be challenged. Liu (2005) points out that the newly introduced market mechanisms have profoundly influenced education finance in China, presenting challenges to education equity. As a result, an ethical appeal is now being made for education equity to be a central feature of education policy. It must be one of the main goals of the education market. As a result, education equity must also incorporate new concepts and ideas such as new definitions of equity and inequity and principles about acceptable differences. New educational institutions may need to be created to cope with conflicts between China's growing market economy and education equity. Yang (2006) analyses the institutional characteristics of education equity in four different phases in modern China, arguing that, since 1977, the main emphasis has shifted from equality of educational rights to equal educational opportunities, raising the bar regarding education quality as well as equity.

The Chinese research community focused on education finance has paid attention to issues of funding adequacy, equity and efficiency. Studies on equity, as mentioned above, are the most rapidly developing field. Quantitative studies are common, utilising national and provincial data collected by the National Bureau of Statistics, the Ministry of Education and the Ministry of Finance on local-level school enrolments, the number and salaries of teachers, school buildings and teaching facilities. While provincial aggregates have been available, lower-level statistics have not. ${ }^{1}$ A big advance of this study is that we have put together a dataset of all county-level governments in China (rural counties, urban districts and county-level cities) for the period since the new, more centralised scheme of education financing was put in place. For this reason, this study carries important significance both for theoretical exploration and for policy formulation.

1 Even though they were not published, statistics on these were collected by relevant government agencies. Wang (2001) and Zeng and Ding (2003, 2005) used local-level education finance statistics collected by the Ministry of Education. 


\section{Modelling funding equity}

The concept of inequity used in this study refers to the gap in the adequacy of education finance between economically more developed and underdeveloped counties within provinces. The gap is an index at the county level - our unit of analysis - and not at the individual student or school level. It measures the dispersion of county-level funding adequacy from the provincial mean. We call it the inequity index: the larger the index, the higher is the inequity within provinces across China.

\section{Dependent variable}

The inequity index is developed from the adequacy index used in an earlier paper by the authors (Hou et al. 2010), as the square of deviation from the mean level of education funding in a province. Constructing an inequity index of basic education inputs in the Chinese context is a dauntingly complex task. We outline below the major steps in constructing this index and the elements we use in the process. This index is our dependent variable.

First, we need to calculate the index from the indicator of adequacy. The calculation of adequacy is based on input and output standards at the provincial level, for two important reasons. First, provinces, not the central government, set the regional standards for all major input and output factors of production. This point is often ignored and misunderstood by people unfamiliar with Chinese government operations; the conventional understanding about China is that, since it is a highly centralised country (under a single dominant political party), everything is set by the central government. That is an oversimplification. On fiscal and managerial matters, the central government has, in fact, decentralised many powers to the provinces in recent years because of its lack of information and for management convenience and the sake of efficiency. Second, provinces, not the central government, redistribute within provincial boundaries, whereas the central government redistributes between provinces according to their level of economic development.

We consider the following elements: 1) enrolments in elementary and middle schools; 2) different ratios of school-age children in rural and urban populations; 3) governmental budgetary input and non-governmental input; 4) teacher-student ratios for elementary and middle schools, and 
the two ratios for urban versus rural areas; 5) teachers' average salary levels in comparison with civil servants at the stipulated provincial level or standard; and 6) operational and facility costs. All factors of production are calculated according to the central government standards set in the 1990s by the Ministry of Education, in 2001 by the Central Office of Government Establishment, the Ministry of Finance, the Ministry of Education and the National Development and Reform Commission in conjunction with the Ministry of Housing and Construction. Thus, we obtain the amount of resources needed to provide the basic, standard level of education in each county-level jurisdiction.

We then calculate the adequacy variable by comparing the difference between our calculated amount and the actual outlay in each county jurisdiction. The difference between the two is the gap between the required and actual amount in a specific county. This gap varies by year and by county. Finally, we get the equity variable from the difference between the individual county's adequacy and the average level within the same province and year. The formulas are provided in Equation 15.1.

\section{Equation 15.1}

$$
\begin{aligned}
& \text { Equiti }_{c, t}=A_{c, t}-\frac{1}{n^{*}} \sum_{c \in C^{*}} A_{c, t} \\
& \text { where } A_{c, t}=\frac{E_{\text {Real }, \mathrm{t}}}{E_{\text {Standard }, \mathrm{t}}}=\frac{E_{\text {Real }, \mathrm{t}}}{\sum_{j} \sum_{i} S_{i, c, t} \times \frac{P_{j, c, t}}{P_{T, c, t}} \times R_{i, j} \times S_{p, t} \times p_{j, p, t} \times e_{p, t}}
\end{aligned}
$$

Equity $_{c, t}$ is the equity of access to education for each year and county (county-level city and district, equivalently); $c \in C^{*}$ represents all the counties in the same province as the target county; $n^{*}$ is the number of counties in the same province as the target county; $A_{c, t}$ is the adequacy of education for each year and county (county-level city and district, equivalently); $E_{\text {Realc, }}$ is the real expenditure on education for each year and county (county-level city and district, equivalently); $E_{\text {Standard,t }}$ is the standard expenditure on education for each year and county (county-level city and district, equivalently); $S_{i, c, t}$ is the number of students for each year $(t)$ and county $(c)$ (county-level city and district, equivalently), by primary/secondary school $(i) ; P_{j, c, t}$ is the population for each year and county (county-level city and district, equivalently), by rural/urban $(j) ; R_{i, j}$ is the teacher-student ratio, by primary/secondary school and by rural/ urban; $S_{p, t}$ is the average public sector salary for each year and province 
(or equivalent administrative region); $p_{j, p, t}$ is the consumer price index (CPI) for each year and province (or equivalent administrative region), by rural/urban; and $e_{p, t}$ is the index for adjusting conceptual and statistical consistency for each year and province (or equivalent administrative region).

We then exclude non-governmental resources from the input side and drop extreme outliers (the top and bottom 5 per cent). Diagnostic analysis shows that this gap (before square) is approximately normally distributed around a mean of zero (though with a longer positive tail than a negative one), as shown in Figure 15.1.

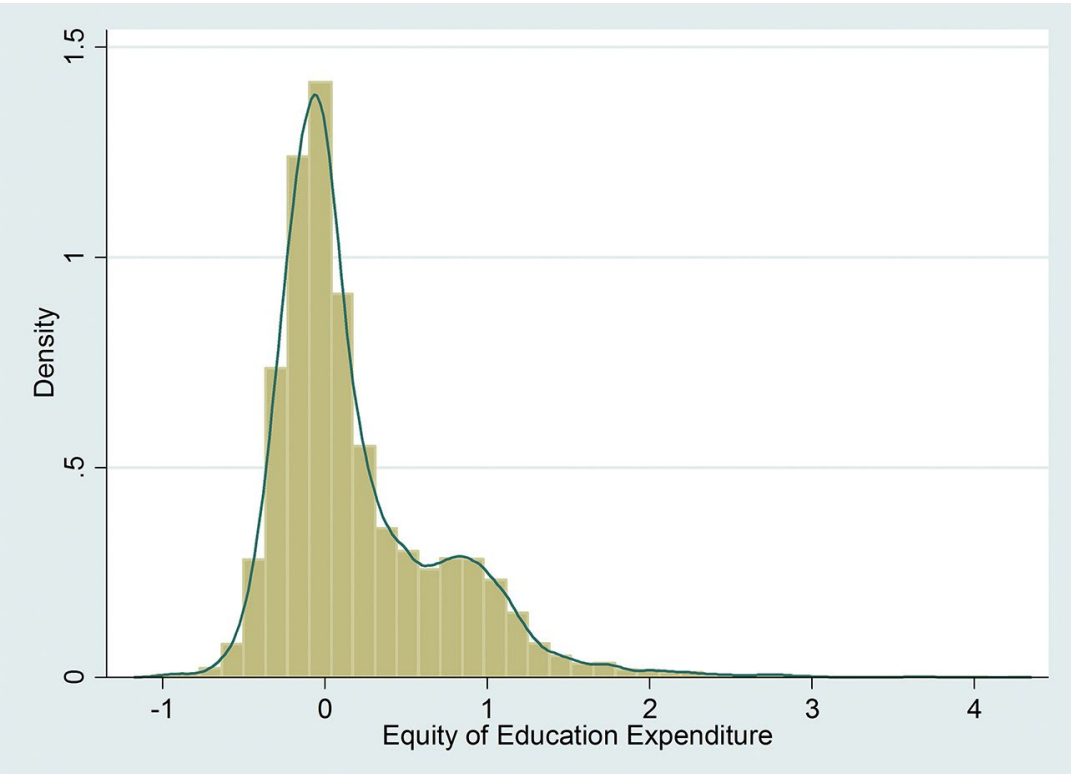

Figure 15.1 Density distribution of the adequacy index with extreme outliers included (all counties in all provinces)

Source: Authors' work.

Based on the equity variable, we use the square of relative mean difference as the dependent variable, which can capture the inequity of education finance in a county (the higher the value in this index, the lower is the funding equity in education finance). Here, $A_{i t}$ can be seen as an indicator of education funding adequacy ( $i$ is county and $t$ is year) (Equation 15.2). 
Equation 15.2

Inequity $_{i t}=\left(\frac{A_{i t}-\mu_{i}}{\mu_{i}}\right)^{2}$

From 2000 to 2006, the aggregate mean of this index trended upwards over time, as shown in Figure 15.2.

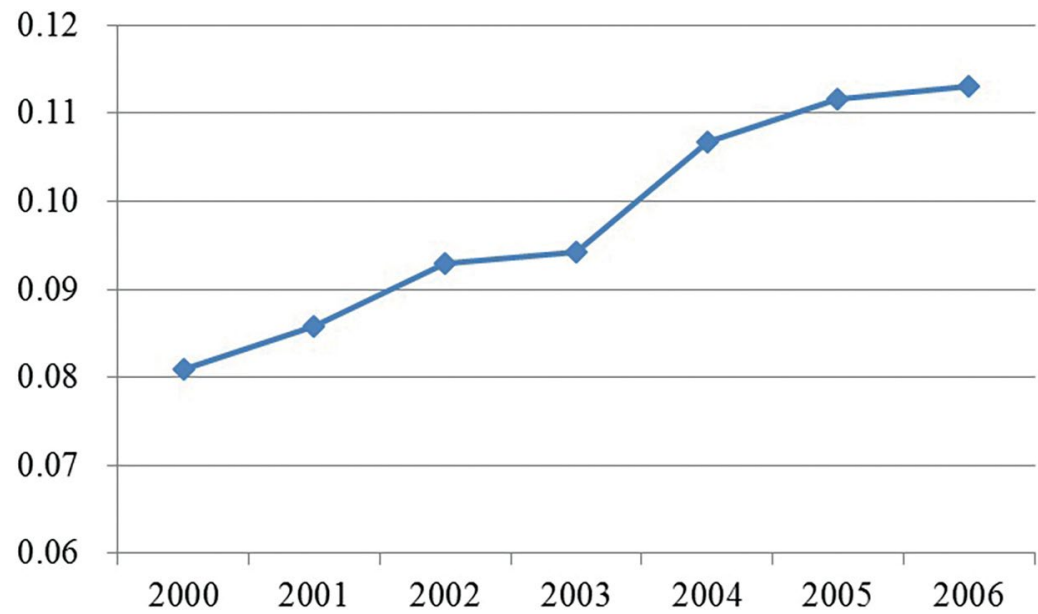

Figure 15.2 Trend change of inequality index over sample period (adequacy)

Source: Authors' work.

\section{Empirical model}

We model the equity of education financing in the Chinese context as follows (Equation 15.3).

Equation 15.3

$E_{c, t}=\mathrm{f}(E C N / F I N, P O L, S, X, T, C)$

In Equation 15.3, $\boldsymbol{E}$ is the funding equity in county $c$ in year $t$. The influencing factors include the local economy, $\boldsymbol{E C N}$, and government revenue, $\boldsymbol{F I N}$, as the base of its finance; the two will be used exclusive of each other in any model specifications due to their strong correlation. $\boldsymbol{P O L}$ (policy) is our key variable block, which includes the chosen level of education expenditure at the per capita level and the amount of fiscal transfers from the central and provincial (subcentral) governments by type 
and use. $S$, the total enrolment of local elementary and middle schools, is also among our key variables. These are all exogenous to local government. $\boldsymbol{X}$ represents the vector of control variables, including demographics, rural-urban divide, financial and geographical typology, employment and major outlay programs. $\boldsymbol{T}$ and $\boldsymbol{C}$ are year and county fixed effects to control for time-invariant and locality-invariant factors.

\section{Explanatory variables}

Our key independent variable is per capita education expenditure. Other key variables are the number of elementary students per village and the number of middle school students per town, both calculated from the ratio of the rural population in the total population, total county enrolments in elementary and middle schools and the number of villages and towns in each county/city. In regard to the local economy, we have per capita gross domestic product (GDP), total employment in public institutions, employment in the agricultural sector and per capita personal savings in the bank. GDP per capita captures the value of the economy in terms of average expenditure per person; employment reflects the degree of urbanisation; and personal savings is a proxy for disposable personal income, which is not available. ${ }^{2}$

As for government finance, we have per capita government revenue from taxes and fees and revenue by its source from the value-added tax (VAT), personal income tax and agricultural tax. The VAT is by far the most important revenue source. This revenue is divided 3:1 between central and provincial governments; within each province, the province, prefecture and county shares of that 25 per cent vary considerably, decided by provincial (sometimes also by prefectural) governments. Personal income tax is important in urban areas where salaries are much higher than in rural areas. This revenue is divided 6:4 between central and provincial governments; each province determines its own division of its 40 per cent share between its layers of government. Agricultural tax refers to a basket of multiple taxes on farm products with different rate structures. In the past few years, the central government has repealed most of these taxes, fundamentally relieving the tax burden on farmers. The remaining few taxes apply primarily to specialty products.

2 Note that some of the four variables may be highly correlated, especially GDP and savings in the bank. We tested the correlation between each pair and confirmed that there is no collinearity problem in the regressions. 
Fiscal transfers represent a major policy change over the past decade of fiscal administration reform. Since 1998, the amount of transfers to localities, especially to poor and rural areas, has increased exponentially. Transfers flow down from the central Ministry of Finance (as well as some other ministries) under multiple names, types and uses; however, they all fall into two categories: one for improving local fiscal capacity and the other for designated purposes. ${ }^{3}$ The former can be used with local discretion; the latter has to be spent on specific projects. Here, we use the total transfers as a ratio against total own-source revenue and also per capita discretionary transfers and per capita special-purpose transfers. For government size and functions, we include expenditure on economic development, administration and law enforcement (public safety, legal and judicial agencies). These three are in per capita terms, converted as the ratio against the provincial average. All financial variables used in this study are deflated by the CPI (with 1993 as the base year).

We control various other aspects of each locality. For demographics, we use population density (per square kilometre) and the natural population growth rate. (We also use the percentage of $0-14$-year-olds and the percentage of those aged 65 years and over, the average years of educational attainment and the illiteracy rate of the population, as well as ethnic minority status [dummy] of the county in the cross-section model.) We also categorise the financial status of localities, controlling for rich counties, subsidy counties and deficit counties—all three as binaries. Rich counties are those that have long been able to collect own-source revenue of more than RMB100 million (A $\$ 18.7$ million) each year and that have generally stable and healthy tax collection systems. Subsidy counties are those that received subsidies in addition to the above transfers; such institutional arrangements started before the transfer scheme began in 1998. Deficit counties are those that have a very limited revenue base and have constantly incurred deficits. Through reviews between county, provincial and central governments, subsidies and deficit allowances are agreed special institutional arrangements. The difference between these two types is, we can reasonably assume, that counties on a preset amount of subsidy face hard budget constraints, while those allowed to incur deficits face a softer budget constraint. In the cross-section model, mountain, minority, pastoral and poverty dummies are used for geographic typology.

3 A third category is called 'tax returns', which are not transfers but a transitional measure as a result of central-provincial bargains in the 1994 tax reform. In this study, we do not consider tax returns as real transfers; however, these are included in the total transfers. 
Data sources are the authoritative annual series for nationwide data: Countrywide Prefecture, City and County Financial Statistics by the Ministry of Finance, China County/City Socio-Economic Annual by the State Statistics Bureau and Countrywide County/City Population Statistics by the Ministry of Public Security. Summary statistics are in Table 15.1. All data are for the period 2000-06.

Table 15.1 Summary statistics of main variables

\begin{tabular}{|l|r|r|r|r|r|}
\hline Variable & No. & Mean & SD & Min. & Max. \\
\hline $\begin{array}{l}\text { EquityEdu (deviation from the mean } \\
\text { divided by mean) }\end{array}$ & 2,604 & 0.15 & 0.36 & -0.37 & 1.17 \\
\hline Inequity index (squared) & 2,604 & 0.15 & 0.26 & 0.00 & 1.38 \\
\hline $\begin{array}{l}\text { Per capita education expenditure } \\
\text { in 1,000 }\end{array}$ & 2,604 & 0.10 & 0.06 & 0.02 & 0.48 \\
\hline Elementary student/village in 1,000 & 2,604 & 0.14 & 0.07 & 0.00 & 0.48 \\
\hline Middle school student/town in 1,000 & 2,604 & 1.81 & 1.00 & 0.00 & 6.19 \\
\hline Per capita local GDP (10,000) & 2,604 & 0.61 & 0.60 & 0.00 & 8.23 \\
\hline $\begin{array}{l}\text { No. of institutional employees per 100 } \\
\text { population }\end{array}$ & 2,604 & 5.37 & 3.82 & 0.97 & 48.95 \\
\hline $\begin{array}{l}\text { No. of agricultural employees per 100 } \\
\text { population }\end{array}$ & 2,604 & 53.82 & 6.80 & 6.94 & 71.85 \\
\hline Per capita personal savings in the bank & 2,604 & 0.34 & 0.29 & 0.02 & 4.22 \\
\hline Per capita tax revenue (1,000) & 2,604 & 0.52 & 0.47 & 0.07 & 6.82 \\
\hline $\begin{array}{l}\text { Revenue from value-added tax } \\
\text { (per capita in 1,000) }\end{array}$ & 2,604 & 0.04 & 0.09 & -0.14 & 1.41 \\
\hline $\begin{array}{l}\text { Revenue from personal income tax } \\
\text { (per capita in 1,000) }\end{array}$ & 2,604 & 0.01 & 0.02 & 0.00 & 0.25 \\
\hline $\begin{array}{l}\text { Revenue from agricultural taxes } \\
\text { (per capita in 1,000) }\end{array}$ & 2,604 & 0.02 & 0.03 & 0.00 & 0.52 \\
\hline Fiscal transfer/own-source revenue ratio & 2,604 & 0.43 & 0.23 & 0.00 & 1.36 \\
\hline Fiscal transfers-discretionary in 1,000 & 2,604 & 0.04 & 0.06 & -0.03 & 0.68 \\
\hline $\begin{array}{l}\text { Fiscal transfers-special purpose } \\
\text { in 1,000 }\end{array}$ & 2,604 & 0.16 & 0.12 & 0.00 & 1.34 \\
\hline $\begin{array}{l}\text { Per capita expenditure on economic } \\
\text { development in 1,000 }\end{array}$ & 2,604 & 0.03 & 0.04 & 0.00 & 0.69 \\
\hline $\begin{array}{l}\text { Per capita expenditure on administration } \\
\text { in 1,000 }\end{array}$ & 2,604 & 0.06 & 0.05 & 0.01 & 0.62 \\
\hline $\begin{array}{l}\text { Per capita expenditure on law } \\
\text { enforcement in 1,000 }\end{array}$ & 2,604 & 0.03 & 0.03 & 0.00 & 0.38 \\
\hline Population density (10,000/km sq) & 2,604 & 0.05 & 0.08 & 0.00 & 3.81 \\
\hline Population growth rate & 0.04 & -0.52 & 1.08 \\
\hline
\end{tabular}


VALUE FOR MONEY

\begin{tabular}{|l|r|r|r|r|r|}
\hline Variable & No. & Mean & SD & Min. & Max. \\
\hline Rich county (binary) & 2,604 & 0.54 & 0.50 & 0.00 & 1.00 \\
\hline County on financial subsidy (binary) & 2,604 & 0.23 & 0.42 & 0.00 & 1.00 \\
\hline County allowed deficit (binary) & 2,604 & 0.27 & 0.45 & 0.00 & 1.00 \\
\hline Year 2000 population growth rate & 606 & 5.77 & 3.38 & -2.70 & 17.81 \\
\hline $\begin{array}{l}\text { Percentage of population aged } \\
\text { O-14 years }\end{array}$ & 606 & 24.40 & 4.46 & 13.10 & 39.36 \\
\hline $\begin{array}{l}\text { Percentage of population aged 65 } \\
\text { and over }\end{array}$ & 606 & 7.42 & 1.61 & 2.92 & 13.47 \\
\hline Average educational attainment & 606 & 7.17 & 0.65 & 3.35 & 9.42 \\
\hline Rate of illiteracy & 606 & 9.92 & 5.78 & 1.33 & 57.59 \\
\hline Percentage of employment in industry & 606 & 13.07 & 11.71 & 0.62 & 67.39 \\
\hline Percentage of employment in services & 606 & 14.16 & 6.63 & 2.56 & 45.11 \\
\hline Mountainous county (binary) & 607 & 0.35 & 0.48 & 0.00 & 1.00 \\
\hline County of minorities (binary) & 607 & 0.11 & 0.32 & 0.00 & 1.00 \\
\hline Pastoral county (binary) & 607 & 0.04 & 0.20 & 0.00 & 1.00 \\
\hline Poor county designation (binary) & 607 & 0.18 & 0.39 & 0.00 & 1.00 \\
\hline VAT shared by provincial government & 563 & 0.05 & 0.04 & 0.00 & 0.13 \\
\hline $\begin{array}{l}\text { Business tax shared by provincial } \\
\text { government }\end{array}$ & 537 & 0.18 & 0.15 & 0.00 & 0.57 \\
\hline $\begin{array}{l}\text { Personal income tax shared } \\
\text { by provincial government }\end{array}$ & 552 & 0.12 & 0.04 & 0.05 & 0.24 \\
\hline $\begin{array}{l}\text { Corporate income tax shared } \\
\text { by provincial government }\end{array}$ & 552 & 0.12 & 0.08 & 0.00 & 0.24 \\
\hline
\end{tabular}

Source: Author's calculation based on compiled data set.

\section{Empirical methodology and results}

We use a fixed-effects estimator with robust standard errors in all the model specifications. We first take a subsample of the total dataset, involving balanced panels of 372 counties across the country. With this set, we use lag operators to identify the effects of the key variables. We then take first difference terms to investigate the effect of changes. Finally, to tease out any endogeneity issues as much as possible, we take the absolute difference in the change of the inequity index between 2000 and 2006, and the independent variables, plug in exogenous controls from the year 2000 census for a cross-sectional examination and use ordinary least squares (OLS) to run the cross-section analysis. 


\section{Model identification}

Table 15.2 illustrates our exploration of a model. The four columns show results of different model specifications. The results show whether the variables fit well in each model and whether their effects are consistent across the four specifications, with different control variables and with or without year dummies. Per capita education expenditure is consistently significant across the different model specifications; it is positive and its magnitude is stable. The positive coefficients illustrate that education expenditure may decrease funding equity, probably because education expenditure is a function of local wealth-that is, localities with high concentrations of wealth tend to invest more heavily in education whereas poor regions cannot.

Table 15.2 Four model specification results without time differences: Impact on inequity index (dependent variable) (fixed-effects estimator with robust standard errors)

\begin{tabular}{|c|c|c|c|c|}
\hline Variables & (1) & (2) & (3) & (4) \\
\hline $\begin{array}{l}\text { Per capita education expenditure } \\
\text { in } 1,000\end{array}$ & $\begin{array}{l}1.3674^{\star \star \star} \\
(0.3220)\end{array}$ & $\begin{array}{l}1.2163^{\star \star \star} \\
(0.3424)\end{array}$ & $\begin{array}{l}1.1067^{\star \star \star} \\
(0.2633)\end{array}$ & $\begin{array}{l}0.9322^{* \star *} \\
(0.3004)\end{array}$ \\
\hline $\begin{array}{l}\text { L. Elementary student/village } \\
\text { in } 1,000\end{array}$ & $\begin{array}{l}-0.0104 \\
(0.0833)\end{array}$ & $\begin{array}{l}-0.0355 \\
(0.0826)\end{array}$ & $\begin{array}{c}0.0132 \\
(0.0809)\end{array}$ & $\begin{array}{l}-0.0040 \\
(0.0778)\end{array}$ \\
\hline $\begin{array}{l}\text { L. Middle school student/town } \\
\text { in } 1,000\end{array}$ & $\begin{array}{l}-0.0057 \\
(0.0069)\end{array}$ & $\begin{array}{l}-0.0086 \\
(0.0069)\end{array}$ & $\begin{array}{l}-0.0083 \\
(0.0068)\end{array}$ & $\begin{array}{l}-0.0127^{*} \\
(0.0068)\end{array}$ \\
\hline L. Per capita local GDP $(10,000)$ & $\begin{array}{c}0.0387 \\
(0.0316) \\
\end{array}$ & & $\begin{array}{c}0.0271 \\
(0.0322) \\
\end{array}$ & \\
\hline $\begin{array}{l}\text { L. No. of institutional employees } \\
\text { per } 100 \text { population }\end{array}$ & $\begin{array}{l}-0.0007 \\
(0.0012)\end{array}$ & & $\begin{array}{l}-0.0006 \\
(0.0012)\end{array}$ & \\
\hline $\begin{array}{l}\text { L. No. of agricultural employees } \\
\text { per } 100 \text { population }\end{array}$ & $\begin{array}{r}-0.0016^{\star} \\
(0.0008) \\
\end{array}$ & & $\begin{array}{l}-0.0023^{\star \star} \\
(0.0009) \\
\end{array}$ & \\
\hline $\begin{array}{l}\text { L. Per capita personal savings } \\
\text { in the bank }\end{array}$ & $\begin{array}{l}-0.0286 \\
(0.0272)\end{array}$ & & $\begin{array}{l}-0.0450 \\
(0.0323)\end{array}$ & \\
\hline L. Per capita tax revenue (in 1,000 ) & & $\begin{array}{c}0.0256 \\
(0.0687) \\
\end{array}$ & & $\begin{array}{l}-0.0052 \\
(0.0732)\end{array}$ \\
\hline $\begin{array}{l}\text { L. Revenue from VAT (per capita } \\
\text { in } 1,000 \text { ) }\end{array}$ & & $\begin{array}{l}0.2364^{*} \\
(0.1425)\end{array}$ & & $\begin{array}{l}0.2767^{\star} \\
(0.1476)\end{array}$ \\
\hline $\begin{array}{l}\text { L. Revenue from personal income } \\
\text { tax (per capita in } 1,000 \text { ) }\end{array}$ & & $\begin{array}{c}0.5922 \\
(0.4731) \\
\end{array}$ & & $\begin{array}{l}0.8826^{\star *} \\
(0.4367) \\
\end{array}$ \\
\hline $\begin{array}{l}\text { L. Revenue from agricultural taxes } \\
\text { (per capita in } 1,000 \text { ) }\end{array}$ & & $\begin{array}{l}0.3420^{* *} \\
(0.1564)\end{array}$ & & $\begin{array}{l}0.3236^{* *} \\
(0.1460)\end{array}$ \\
\hline $\begin{array}{l}\text { L. Fiscal transfer/own-source } \\
\text { revenue ratio }\end{array}$ & $\begin{array}{l}0.1271^{* *} \\
(0.0514)\end{array}$ & $\begin{array}{l}0.1708^{* \star *} \\
(0.0603)\end{array}$ & $\begin{array}{c}0.0335 \\
(0.0473)\end{array}$ & $\begin{array}{c}0.0618 \\
(0.0546)\end{array}$ \\
\hline
\end{tabular}


VALUE FOR MONEY

\begin{tabular}{|c|c|c|c|c|}
\hline Variables & (1) & (2) & (3) & (4) \\
\hline $\begin{array}{l}\text { L. Fiscal transfers - discretionary } \\
\text { in } 1,000\end{array}$ & $\begin{array}{c}0.0893 \\
(0.1404) \\
\end{array}$ & $\begin{array}{l}0.0809 \\
(0.1522) \\
\end{array}$ & $\begin{array}{l}-0.0306 \\
(0.1349) \\
\end{array}$ & $\begin{array}{l}-0.0248 \\
(0.1576) \\
\end{array}$ \\
\hline $\begin{array}{l}\text { L. Fiscal transfers-special purpose } \\
\text { in } 1,000\end{array}$ & $\begin{array}{l}-0.0551 \\
(0.0929)\end{array}$ & $\begin{array}{l}-0.0473 \\
(0.0982)\end{array}$ & $\begin{array}{l}-0.1192 \\
(0.0900)\end{array}$ & $\begin{array}{l}-0.0903 \\
(0.1103)\end{array}$ \\
\hline $\begin{array}{l}\text { L. Outlay on economic development } \\
\text { as ratio of provincial average }\end{array}$ & $\begin{array}{l}-0.0012 \\
(0.0042) \\
\end{array}$ & $\begin{array}{l}-0.0033 \\
(0.0044) \\
\end{array}$ & $\begin{array}{c}0.0012 \\
(0.0042) \\
\end{array}$ & $\begin{array}{l}-0.0007 \\
(0.0043) \\
\end{array}$ \\
\hline $\begin{array}{l}\text { L. Outlay on administration as ratio } \\
\text { of provincial average }\end{array}$ & $\begin{array}{c}0.0238 \\
(0.0181)\end{array}$ & $\begin{array}{l}0.0106 \\
(0.0192)\end{array}$ & $\begin{array}{c}0.0259 \\
(0.0187)\end{array}$ & $\begin{array}{l}0.0118 \\
(0.0203)\end{array}$ \\
\hline $\begin{array}{l}\text { L. Outlay on law enforcement } \\
\text { as ratio of provincial average }\end{array}$ & $\begin{array}{c}0.0126 \\
(0.0195)\end{array}$ & $\begin{array}{l}0.0018 \\
(0.0173)\end{array}$ & $\begin{array}{l}0.0217 \\
(0.0206)\end{array}$ & $\begin{array}{c}0.0102 \\
(0.0182)\end{array}$ \\
\hline Population density $(10,000 / \mathrm{km} \mathrm{sq})$ & $\begin{array}{c}0.0029 \\
(0.0056)\end{array}$ & $\begin{array}{c}0.0028 \\
(0.0056)\end{array}$ & $\begin{array}{c}0.0049 \\
(0.0053)\end{array}$ & $\begin{array}{l}0.0045 \\
(0.0054)\end{array}$ \\
\hline Population growth rate & $\begin{array}{l}-0.0007 \\
(0.0394) \\
\end{array}$ & $\begin{array}{l}-0.0165 \\
(0.0435) \\
\end{array}$ & $\begin{array}{l}-0.0001 \\
(0.0382) \\
\end{array}$ & $\begin{array}{l}-0.0169 \\
(0.0428) \\
\end{array}$ \\
\hline Rich county (binary) & $\begin{array}{l}0.0135 \\
(0.0106)\end{array}$ & $\begin{array}{l}0.0141 \\
(0.0108) \\
\end{array}$ & $\begin{array}{l}0.0060 \\
(0.0104) \\
\end{array}$ & $\begin{array}{c}0.0070 \\
(0.0107) \\
\end{array}$ \\
\hline County on financial subsidy (binary) & $\begin{array}{l}-0.0277^{\star \star \star} \\
(0.0100)\end{array}$ & $\begin{array}{c}-0.0276^{\star \star \star} \\
(0.0101) \\
\end{array}$ & $\begin{array}{c}-0.0286^{\star \star \star} \\
(0.0092) \\
\end{array}$ & $\begin{array}{c}-0.0282^{\star \star \star} \\
(0.0094) \\
\end{array}$ \\
\hline County allowed deficit (binary) & $\begin{array}{l}-0.0084 \\
(0.0190) \\
\end{array}$ & $\begin{array}{l}-0.0081 \\
(0.0192) \\
\end{array}$ & $\begin{array}{l}-0.0058 \\
(0.0189) \\
\end{array}$ & $\begin{array}{l}-0.0055 \\
(0.0191) \\
\end{array}$ \\
\hline y2002 & $\begin{array}{c}-0.0191^{\star *} \\
(0.0076)\end{array}$ & $\begin{array}{c}-0.0241^{\star \star \star} \\
(0.0075)\end{array}$ & & \\
\hline y2003 & $\begin{array}{c}-0.0238^{\star \star} \\
(0.0109)\end{array}$ & $\begin{array}{c}-0.0305^{\star \star \star} \\
(0.0107) \\
\end{array}$ & & \\
\hline y2004 & $\begin{array}{c}-0.0322^{\star \star} \\
(0.0132) \\
\end{array}$ & $\begin{array}{c}-0.0407^{\star \star \star} \\
(0.0129) \\
\end{array}$ & & \\
\hline y2005 & $\begin{array}{c}-0.0616^{\star \star \star} \\
(0.0185)\end{array}$ & $\begin{array}{c}-0.0676^{\star \star \star} \\
(0.0171) \\
\end{array}$ & & \\
\hline y2006 & $\begin{array}{c}-0.0714^{\star \star \star} \\
(0.0247)\end{array}$ & $\begin{array}{c}-0.0777^{\star \star \star} \\
(0.0224)\end{array}$ & & \\
\hline Constant & $\begin{array}{c}0.0573 \\
(0.0545)\end{array}$ & $\begin{array}{l}-0.0229 \\
(0.0378)\end{array}$ & $\begin{array}{c}0.1410^{\star \star \star} \\
(0.0501)\end{array}$ & $\begin{array}{c}0.0270 \\
(0.0312)\end{array}$ \\
\hline Observations & 2232 & 2232 & 2232 & 2232 \\
\hline R-squared & 0.197 & 0.209 & 0.178 & 0.188 \\
\hline
\end{tabular}

${ }^{*} p<0.10$

${ }^{* *} p<0.05$

*** $\mathrm{p}<0.01$

Note: Robust standard errors in parentheses. $L=$ one-year lag.

Source: Regression result based on compiled data. 
The number of elementary school students per village and the number of middle school students per town are both negative but not significant. This result is broadly consistent across the specifications, indicating that there are no direct effects of school enrolment on funding equity. Among measures of the local economy, only employment in the agricultural sector shows a significant effect on the inequity index in the two models testing this variable. Since counties with higher levels of agricultural employment usually are less developed, the negative sign indicates that, as agricultural employment drops towards the provincial mean, equity is likely to improve even though a more developed county may be higher than the mean, increasing the inequity index. However, the coefficient of this variable is very small. Among government finance variables, most of the revenue sources seem to work towards increasing inequity (the index). Revenues from the VAT and the agricultural tax are consistently significant. While more own-source revenue provides the average county an edge in funding adequacy, it decreases equity across counties in the province due to the effect of resource concentration. In other words, counties with more own-source revenue are those that are likely to achieve funding adequacy (or higher).

Fiscal transfers to poor localities are a major policy instrument that the Chinese central and provincial governments have been using in recent years to improve education funding equity. Here they are measured as a ratio against total own-source revenue on a per capita basis. Perhaps surprisingly, fiscal transfers are significant and positive, decreasing equity. The reason could be that the total fiscal transfer is an aggregate measure that includes tax returns, which, to a large extent, reflects the level of local economic development. ${ }^{4}$ Discretionary transfers and special-purpose transfers are not significant. This may be because these transfers are mainly directed towards reducing interprovincial disparity and do not help to decrease intraprovincial inequity, which is what is measured in this chapter. The results are also consistent with the conclusion by $\mathrm{Wu}$ and Wang (2013) that provincial governments may have grabbed central grants for their own self-interest. Variables on government size and functions do not have statistically significant effects on funding equity.

4 As the tax returns are generated entirely locally, we also add them to the own-source revenue as alternative tests for each regression and find that the effects are even more significant, which confirms our overall results. 
Of the other control variables, demographic factors are not significant in any of the model specifications. In the financial category of localities, the coefficients of subsidy counties are consistently significant. The likely reason is that subsidy counties tend to have more rural areas, where the subsidy can greatly help to raise the level of education funding and thereby increase the adequacy and equity of funding. Coefficients on the year effects are consistently negative and significant in all the years (year 2001 as default) across most models. The coefficients become largely negative from 2002 each year until 2006, indicating that the macro policy became more effective over the sample period - that is, some fixed factors across years have increased the equity of education funding, such as policies to widen economic growth in western and central provinces.

\section{Difference measures of education expenditure: Full model specification}

Next we use a full model specification with the difference measure (current year minus previous year). There are several reasons for this operation. Since we found in the above results (Table 15.2) that the coefficients on the year effects are consistently negative and significant over all the years compared with 2001, we want to estimate the effects of the yearby-year change in education outlays. Also, using the difference measure can effectively help eliminate multicollinearity in the variables. Finally, the mismatch between the fiscal year (January-December) and the school year (September-August) may extend the impact of a current budget on schools over two years. The results are presented in Table 15.3 with the dependent variable (inequity index) in both the level scale $(D V=$ inequity index) and the difference scale $\left(D V=\right.$ inequity $_{t}-$ inequity $\left._{t-1}\right)$.

Table 15.3 Model including difference measures (inequity index)

\begin{tabular}{|l|c|c|c|c|}
\hline \multirow{2}{*}{ Variables } & \multicolumn{2}{|c|}{ DV in level } & \multicolumn{2}{c|}{ DV in first difference } \\
\cline { 2 - 5 } & $(1)$ & $(2)$ & $(3)$ & $(4)$ \\
\hline D. Per capita education expenditure & $1.5515^{\star \star \star}$ & $1.7239^{\star \star \star}$ & $\begin{array}{c}2.5970^{\star \star \star} \\
(0.5161)\end{array}$ & $\begin{array}{c}2.7818^{\star \star \star} \\
(0.5199)\end{array}$ \\
\hline in 1,000 & $(0.3238)$ & $(0.3186)$ & $(0.516)$ & 0.1487 \\
\hline D. Elementary student/village in & 0.1445 & 0.1246 & 0.1453 & 0.1487 \\
1,000 & $(0.0903)$ & $(0.0819)$ & $(0.1044)$ & $(0.0944)$ \\
\hline D. Middle school student/town in & $-0.0115^{\star \star}$ & -0.0036 & -0.0066 & -0.0000 \\
1,000 & $(0.0050)$ & $(0.0047)$ & $(0.0073)$ & $(0.0071)$ \\
\hline D. Per capita tax revenue $(1,000)$ & $0.3002^{\star \star}$ & $0.2655^{\star *}$ & -0.0348 & -0.0539 \\
& $(0.1290)$ & $(0.1233)$ & $(0.0934)$ & $(0.0876)$ \\
\hline
\end{tabular}




\begin{tabular}{|c|c|c|c|c|}
\hline \multirow[t]{2}{*}{ Variables } & \multicolumn{2}{|c|}{ DV in level } & \multicolumn{2}{|c|}{ DV in first difference } \\
\hline & (1) & (2) & (3) & (4) \\
\hline $\begin{array}{l}\text { D. Revenue from VAT (per capita in } \\
1,000 \text { ) }\end{array}$ & $\begin{array}{l}-0.0883 \\
(0.0649)\end{array}$ & $\begin{array}{l}-0.0525 \\
(0.0661)\end{array}$ & $\begin{array}{c}0.0444 \\
(0.0784)\end{array}$ & $\begin{array}{c}0.0580 \\
(0.0799)\end{array}$ \\
\hline $\begin{array}{l}\text { D. Revenue from personal income } \\
\text { tax (per capita in } 1,000 \text { ) }\end{array}$ & $\begin{array}{l}-0.1779 \\
(0.3577) \\
\end{array}$ & $\begin{array}{c}0.2326 \\
(0.3992) \\
\end{array}$ & $\begin{array}{l}-0.5458 \\
(0.3701) \\
\end{array}$ & $\begin{array}{c}0.0729 \\
(0.4282)\end{array}$ \\
\hline $\begin{array}{l}\text { D. Revenue from agricultural taxes } \\
\text { (per capita in } 1,000 \text { ) }\end{array}$ & $\begin{array}{l}-0.2604 \\
(0.1766) \\
\end{array}$ & $\begin{array}{l}-0.2571 \\
(0.2251) \\
\end{array}$ & $\begin{array}{c}0.1203 \\
(0.1130) \\
\end{array}$ & $\begin{array}{l}0.0835 \\
(0.1361) \\
\end{array}$ \\
\hline $\begin{array}{l}\text { D. Fiscal transfer/own-source } \\
\text { revenue ratio }\end{array}$ & $\begin{array}{c}0.0550 \\
(0.0679) \\
\end{array}$ & $\begin{array}{l}0.2166^{\star \star \star} \\
(0.0737)\end{array}$ & $\begin{array}{l}-0.0406 \\
(0.0547) \\
\end{array}$ & $\begin{array}{l}0.1296^{\star} \\
(0.0668) \\
\end{array}$ \\
\hline $\begin{array}{l}\text { D. Fiscal transfers-discretionary } \\
\text { in } 1,000\end{array}$ & $\begin{array}{c}-0.5089^{\star \star \star} \\
(0.1857)\end{array}$ & \begin{tabular}{|c}
$-0.5685^{\star \star \star}$ \\
$(0.1691)$
\end{tabular} & $\begin{array}{c}-0.2184^{\star} \\
(0.1185)\end{array}$ & $\begin{array}{c}-0.2671^{\star \star} \\
(0.1106) \\
\end{array}$ \\
\hline $\begin{array}{l}\text { D. Fiscal transfers-special purpose } \\
\text { in } 1,000\end{array}$ & $\begin{array}{l}-0.4118^{* *} \\
(0.2047)\end{array}$ & $\begin{array}{c}-0.5517^{\star \star \star} \\
(0.1934)\end{array}$ & $\begin{array}{l}-0.1148 \\
(0.1423)\end{array}$ & $\begin{array}{c}-0.2481^{*} \\
(0.1441)\end{array}$ \\
\hline $\begin{array}{l}\text { D. Outlay on economic } \\
\text { development as ratio of average }\end{array}$ & $\begin{array}{l}-0.0083^{*} \\
(0.0046) \\
\end{array}$ & $\begin{array}{l}-0.0061 \\
(0.0045) \\
\end{array}$ & $\begin{array}{l}-0.0003 \\
(0.0047) \\
\end{array}$ & $\begin{array}{c}0.0014 \\
(0.0048)\end{array}$ \\
\hline $\begin{array}{l}\text { D. Outlay on administration as ratio } \\
\text { of average }\end{array}$ & $\begin{array}{c}-0.0587^{\star \star \star} \\
(0.0176)\end{array}$ & $\begin{array}{c}-0.0523^{\star \star \star} \\
(0.0168)\end{array}$ & $\begin{array}{c}-0.0590^{\star \star \star} \\
(0.0184)\end{array}$ & $\begin{array}{c}-0.0558^{\star \star \star} \\
(0.0187)\end{array}$ \\
\hline $\begin{array}{l}\text { D. Outlay on law enforcement as } \\
\text { ratio of average }\end{array}$ & $\begin{array}{c}-0.0400^{\star \star \star} \\
(0.0120)\end{array}$ & \begin{tabular}{|c|}
$-0.0342^{\star \star \star}$ \\
$(0.0117)$
\end{tabular} & $\begin{array}{l}-0.0342^{\star \star} \\
(0.0144)\end{array}$ & $\begin{array}{c}-0.0313^{\star \star} \\
(0.0147)\end{array}$ \\
\hline D. Population density $(10,000 / \mathrm{km} \mathrm{sq})$ & $\begin{array}{l}0.0086^{\star \star \star} \\
(0.0033) \\
\end{array}$ & $\begin{array}{l}0.0097^{\star \star \star} \\
(0.0035)\end{array}$ & $\begin{array}{l}0.0094^{\star \star \star} \\
(0.0027)\end{array}$ & $\begin{array}{c}0.0114^{\star \star \star} \\
(0.0032)\end{array}$ \\
\hline Population growth rate & $\begin{array}{c}0.0350 \\
(0.0439)\end{array}$ & $\begin{array}{c}0.0379 \\
(0.0440)\end{array}$ & $\begin{array}{l}-0.0186 \\
(0.0599)\end{array}$ & $\begin{array}{l}-0.0108 \\
(0.0597)\end{array}$ \\
\hline Year dummies & No & Yes & No & Yes \\
\hline Observations & 2232 & 2232 & 2232 & 2232 \\
\hline R-squared & 0.156 & 0.196 & 0.168 & 0.198 \\
\hline
\end{tabular}

${ }^{*} p<0.10$

${ }^{* *} p<0.05$

${ }^{* * *} p<0.01$

Notes: Coefficients of dummy variables for financial status of counties are not shown in the table (available from the authors on request). Robust standard errors are in parentheses. Dependent variable (DV) in level indicates that the dependent variable is the inequity index, while DV in first difference indicates that the dependent variable is measured by first difference - that is, $\left(D V=\right.$ inequity $_{t}-$ inequity $\left._{\mathrm{t}-1}\right)$. $\mathrm{D}=$ first difference.

Source: Regression result based on compiled data.

The results show that increases in the difference of per capita education outlay may raise the inequity index (i.e. decrease funding equity). Both the per village elementary student variable and the per town middle school student variable keep their insignificance in effect on equity, as they did in Table 15.2 across most models. One significant coefficient for per town middle school students may imply a large student body 
can be an indicator of economic scale. For a county with high education funding adequacy, larger student bodies drag down spending relative to the provincial average and thereby increase equity. For a county with low adequacy, by contrast, larger student bodies may be correlated with more funding sources and therefore can increase both adequacy and equity.

On the revenue side, the difference in per capita total tax revenue has a significant positive coefficient while the difference in tax structure has no significant impact in the difference model. This makes sense since the tax structure is an indicator of the status of a county that does not change much in a short time. That is why the level of different tax revenue matters while the change in the structure does not give us more information about education funding. The change in total tax revenue can increase funding and, from the positive coefficients, we can conclude that the change in tax revenue is larger for rich counties (with higher adequacy) so the change increases the index and decreases funding equity. China has now abolished agricultural taxes on most staple farm produce, which effectively eliminates any potential effect of the agricultural tax on education outlay. Previously, however, the agricultural tax helped to raise the education funding level (adequacy).

On the policy side, changes in both discretionary and special transfers become very significant and are negative-improving equity-in this comprehensive model using differences rather than just levels. This makes sense because the changes are very different from the levels of transfers. The model eliminates the basic level of transfers, including tax rebates, a large part of which reflects the extent of economic development. The change in fiscal transfer payments is helping local governments to improve public services such as basic education, as intended by central and provincial governments. The transfers-own-source revenue ratio, however, turns out to be positive and significant in some models, reducing equity, which is understandable since the ratio change depends on the changes of both transfers and own-source revenue. Changes in government size and functions also help to increase the funding equity level, which illustrates the role of government in public service provision, including education.

Of the control variables, the population growth rate is not significant in the short term. Population density is significantly positive. Changes in population density in the short term would largely be due to the influx (or outflow) of population. An influx increases the index level and thus decreases funding equity, which probably relates to rich counties 
attracting labour from other places, and these counties having higher funding inequity. Most of the dummies for the financial status of counties are not significant since they do not change much in the difference model.

\section{Explaining the six-year difference}

As Figure 15.2 indicates, the education funding inequity index trends upwards (increasing gap) over the sample period, which is in line with China's economic development and drastic increases in (especially local) government input into education in wealthier counties. In general, it can be said that the central and provincial governments' policy for redistribution and equity has not shown the expected achievements in reducing the interregional gap within provinces, though it may have dampened the increasing trend of inequity (and may also have decreased interprovincial inequity, which is not examined in this study). To better capture this effect, we calculate the difference in the index between 2000 and 2006, also taking the six-year difference for most independent variables used in the above analysis. We then plug in county-level control variables from the 2000 census as exogenous background. With this exercise, we may be able to offer another perspective on the overall effects of the policy shock in the sample period. The sample size of this cross-sectional analysis ranges from 525 to 606 counties in four specifications. Results of the OLS analysis are offered in Table 15.4.

Table 15.4 Cross-section model, dependent variable = inequity index difference between 2006 and 2000

\begin{tabular}{|l|c|c|c|c|}
\hline & $(1)$ & $(2)$ & $(3)$ & $(4)$ \\
\hline Variables & \multicolumn{3}{|c|}{ Dependent variable $=2006-2000$} \\
\hline $\begin{array}{l}\text { Per capita education expenditure } \\
\text { in 1,000 }\end{array}$ & $\begin{array}{c}0.0004^{\star *} \\
(0.0002)\end{array}$ & $\begin{array}{c}0.0005^{\star *} \\
(0.0002)\end{array}$ & $\begin{array}{c}0.0007^{\star * *} \\
(0.0002)\end{array}$ & $\begin{array}{c}0.0012^{\star * *} \\
(0.0002)\end{array}$ \\
\hline Elementary student/village in 1,000 & -0.1487 & -0.1178 & -0.1221 & -0.0822 \\
& $(0.0986)$ & $(0.0999)$ & $(0.1051)$ & $(0.1189)$ \\
\hline Middle school student/town & -0.0113 & -0.0106 & -0.0117 & -0.0060 \\
in 1,000 & $(0.0092)$ & $(0.0096)$ & $(0.0096)$ & $(0.0106)$ \\
\hline Per capita tax revenue $(1,000)$ & $0.9064^{*}$ & 0.7539 & $0.8247^{\star}$ & -0.6449 \\
& $(0.4701)$ & $(0.4926)$ & $(0.5006)$ & $(0.5735)$ \\
\hline Revenue from VAT (per capita & $0.0003^{*}$ & $0.0003^{*}$ & $0.0003^{*}$ & -0.0000 \\
in 1,000) & $(0.0002)$ & $(0.0002)$ & $(0.0002)$ & $(0.0002)$ \\
\hline Revenue from personal income tax & -0.0008 & -0.0007 & -0.0007 & -0.0010 \\
(per capita in 1,000) & $(0.0007)$ & $(0.0007)$ & $(0.0007)$ & $(0.0007)$ \\
\hline
\end{tabular}


VALUE FOR MONEY

\begin{tabular}{|c|c|c|c|c|}
\hline & (1) & (2) & (3) & (4) \\
\hline Variables & \multicolumn{4}{|c|}{ Dependent variable $=2006-2000$} \\
\hline $\begin{array}{l}\text { Revenue from agricultural taxes } \\
\text { (per capita in 1,000) }\end{array}$ & $\begin{array}{l}0.0013^{\star \star \star} \\
(0.0003)\end{array}$ & $\begin{array}{l}0.0013^{\star \star \star} \\
(0.0003)\end{array}$ & $\begin{array}{c}0.0013^{\star \star \star} \\
(0.0003)\end{array}$ & $\begin{array}{c}0.0016^{\star \star \star} \\
(0.0003)\end{array}$ \\
\hline $\begin{array}{l}\text { Fiscal transfer/own-source } \\
\text { revenue ratio }\end{array}$ & $\begin{array}{l}0.2251^{\star \star \star} \\
(0.0481)\end{array}$ & $\begin{array}{l}0.2062^{\star \star *} \\
(0.0489)\end{array}$ & $\begin{array}{c}0.2079^{\star \star \star} \\
(0.0526)\end{array}$ & $\begin{array}{c}0.0916 \\
(0.0573) \\
\end{array}$ \\
\hline $\begin{array}{l}\text { Fiscal transfers-discretionary } \\
\text { in } 1,000\end{array}$ & $\begin{array}{l}0.3958^{\star \star \star} \\
(0.1163)\end{array}$ & $\begin{array}{l}0.4294^{\star \star \star} \\
(0.1185)\end{array}$ & $\begin{array}{c}0.3640^{\star \star \star} \\
(0.1257) \\
\end{array}$ & $\begin{array}{c}0.3674^{\star \star \star} \\
(0.1297)\end{array}$ \\
\hline $\begin{array}{l}\text { Fiscal transfers-special purpose } \\
\text { in } 1,000\end{array}$ & $\begin{array}{l}-0.0331 \\
(0.0829)\end{array}$ & $\begin{array}{l}-0.0482 \\
(0.0843)\end{array}$ & $\begin{array}{c}-0.1661^{*} \\
(0.0935)\end{array}$ & $\begin{array}{l}0.0917 \\
(0.0998)\end{array}$ \\
\hline $\begin{array}{l}\text { Outlay on economic development } \\
\text { as ratio of average }\end{array}$ & $\begin{array}{c}0.0023 \\
(0.0050)\end{array}$ & $\begin{array}{c}0.0027 \\
(0.0050) \\
\end{array}$ & $\begin{array}{c}0.0028 \\
(0.0051) \\
\end{array}$ & $\begin{array}{c}0.0023 \\
(0.0053) \\
\end{array}$ \\
\hline $\begin{array}{l}\text { Outlay on administration as ratio } \\
\text { of average }\end{array}$ & $\begin{array}{l}0.0373 \\
(0.0247)\end{array}$ & $\begin{array}{c}0.0363 \\
(0.0247)\end{array}$ & $\begin{array}{l}0.0399 \\
(0.0254)\end{array}$ & $\begin{array}{l}0.0492^{\star} \\
(0.0285)\end{array}$ \\
\hline $\begin{array}{l}\text { Outlay on law enforcement as ratio } \\
\text { of average }\end{array}$ & $\begin{array}{l}0.0411^{\star} \\
(0.0234)\end{array}$ & $\begin{array}{l}0.0406^{*} \\
(0.0235) \\
\end{array}$ & $\begin{array}{l}0.0446^{\star} \\
(0.0236) \\
\end{array}$ & $\begin{array}{c}0.0360 \\
(0.0271) \\
\end{array}$ \\
\hline Population density (10,000/km sq) & $\begin{array}{c}1.4092 \\
(1.3095)\end{array}$ & $\begin{array}{c}1.5444 \\
(1.3511) \\
\end{array}$ & $\begin{array}{c}1.3366 \\
(1.3543)\end{array}$ & $\begin{array}{c}1.5312 \\
(1.3407) \\
\end{array}$ \\
\hline Rich county (binary) & $\begin{array}{l}0.0117 \\
(0.0150)\end{array}$ & $\begin{array}{c}0.0046 \\
(0.0155) \\
\end{array}$ & $\begin{array}{c}0.0039 \\
(0.0158) \\
\end{array}$ & $\begin{array}{c}0.0031 \\
(0.0164) \\
\end{array}$ \\
\hline County on financial subsidy (binary) & $\begin{array}{l}-0.0122 \\
(0.0154)\end{array}$ & $\begin{array}{l}-0.0167 \\
(0.0158) \\
\end{array}$ & $\begin{array}{l}-0.0203 \\
(0.0177) \\
\end{array}$ & $\begin{array}{l}-0.0297 \\
(0.0208) \\
\end{array}$ \\
\hline County allowed deficit (binary) & $\begin{array}{l}0.0101 \\
(0.0139)\end{array}$ & $\begin{array}{c}0.0068 \\
(0.0140)\end{array}$ & $\begin{array}{c}0.0066 \\
(0.0144)\end{array}$ & $\begin{array}{l}-0.0030 \\
(0.0144)\end{array}$ \\
\hline Year 2000 population growth rate & & $\begin{array}{l}-0.0051^{*} \\
(0.0027)\end{array}$ & $\begin{array}{c}-0.0061^{\star *} \\
(0.0028)\end{array}$ & $\begin{array}{c}-0.0095^{\star \star \star} \\
(0.0033)\end{array}$ \\
\hline $\begin{array}{l}\text { Percentage of population aged } \\
0-14 \text { years }\end{array}$ & & $\begin{array}{l}-0.0005 \\
(0.0021) \\
\end{array}$ & $\begin{array}{l}-0.0003 \\
(0.0023) \\
\end{array}$ & $\begin{array}{c}0.0036 \\
(0.0027) \\
\end{array}$ \\
\hline $\begin{array}{l}\text { Percentage of population aged } 65 \\
\text { and over }\end{array}$ & & $\begin{array}{l}-0.0080 \\
(0.0052) \\
\end{array}$ & $\begin{array}{l}-0.0053 \\
(0.0054) \\
\end{array}$ & $\begin{array}{l}-0.0035 \\
(0.0060) \\
\end{array}$ \\
\hline Average educational attainment & & & $\begin{array}{c}0.0076 \\
(0.0197)\end{array}$ & $\begin{array}{l}0.0374^{\star} \\
(0.0222)\end{array}$ \\
\hline Rate of illiteracy & & & $\begin{array}{l}-0.0023 \\
(0.0020)\end{array}$ & $\begin{array}{c}0.0013 \\
(0.0022)\end{array}$ \\
\hline Percentage employment in industry & & & $\begin{array}{c}-0.0028^{\star \star \star} \\
(0.0010)\end{array}$ & $\begin{array}{l}-0.0008 \\
(0.0012)\end{array}$ \\
\hline Percentage employment in services & & & $\begin{array}{l}0.0030^{*} \\
(0.0015) \\
\end{array}$ & $\begin{array}{l}0.0034^{\star \star} \\
(0.0015)\end{array}$ \\
\hline Mountainous county (binary) & & & $\begin{array}{l}-0.0055 \\
(0.0145) \\
\end{array}$ & $\begin{array}{l}-0.0019 \\
(0.0148) \\
\end{array}$ \\
\hline County of minorities (binary) & & & $\begin{array}{c}0.0363 \\
(0.0279)\end{array}$ & $\begin{array}{l}-0.0371 \\
(0.0360)\end{array}$ \\
\hline
\end{tabular}




\begin{tabular}{|c|c|c|c|c|}
\hline & (1) & (2) & (3) & (4) \\
\hline Variables & \multicolumn{4}{|c|}{ Dependent variable $=2006-2000$} \\
\hline Pastoral county (binary) & & & $\begin{array}{l}-0.0329 \\
(0.0354)\end{array}$ & $\begin{array}{l}-0.0242 \\
(0.0370)\end{array}$ \\
\hline Poor county designation & & & $\begin{array}{l}0.0366^{\star} \\
(0.0189)\end{array}$ & $\begin{array}{l}0.0307 \\
(0.0193)\end{array}$ \\
\hline VAT shared by provincial government & & & & $\begin{array}{c}0.3539 \\
(0.2283)\end{array}$ \\
\hline $\begin{array}{l}\text { Business tax shared by provincial } \\
\text { government }\end{array}$ & & & & $\begin{array}{c}-0.3177^{\star \star \star} \\
(0.0763)\end{array}$ \\
\hline $\begin{array}{l}\text { Personal income tax shared } \\
\text { by provincial government }\end{array}$ & & & & $\begin{array}{c}0.8621^{\star \star \star} \\
(0.2771)\end{array}$ \\
\hline $\begin{array}{l}\text { Corporate income tax shared } \\
\text { by provincial government }\end{array}$ & & & & $\begin{array}{c}-0.3971^{* \star *} \\
(0.1289)\end{array}$ \\
\hline Constant & $\begin{array}{c}-0.1309^{* \star *} \\
(0.0252)\end{array}$ & $\begin{array}{l}-0.0143 \\
(0.0766)\end{array}$ & $\begin{array}{l}-0.0735 \\
(0.1799)\end{array}$ & $\begin{array}{r}-0.4305^{*} \\
(0.2266)\end{array}$ \\
\hline Observations & 607 & 606 & 606 & 525 \\
\hline R-squared & 0.233 & 0.241 & 0.265 & 0.230 \\
\hline
\end{tabular}

${ }^{*} p<0.10$

${ }^{* *} p<0.05$

*** $\mathrm{p}<0.01$

Notes: Coefficients for other control variables are not shown in the table (available from the authors on request). Robust standard errors are in parentheses.

Source: Regression result based on compiled data.

For intergovernmental transfers, the coefficients of discretionary transfers are positive and significant, while special transfers are negative but with less statistical significance. The transfer-tax revenue ratio is also positive and significant. These results suggest that transfers have not led to more equitable funding for poor counties in central and western provinces, but have adversely increased intraprovincial inequity, probably because the 'tax return' embedded in the transfer mechanism led to higher local revenue in the more rapidly developing areas.

As in previous models, changes in the number of primary or middle school students do not have an effect on the inequity index. For total tax revenue and revenue by tax type, some are significant and positive. For example, agricultural taxes were repealed during this period, stripping rural counties of their stable own-source revenue, thus increasing the inequity index. By taking the 2006-2000 difference, we capture the effect of this change. Government outlays do not have a consistent effect on the inequity index and the same is true of the financial status of these counties. 
Of the control variables from the 2000 census, the natural population growth rate negatively impacts the inequity index, increasing funding equity, which is probably because the funding formula contains a factor of population and school enrolment. The change in average educational attainment exerts a positive impact on the inequity index and decreases funding equity since higher educational attainment indicates better economic conditions for the county-that is, localities with higher average education levels will favour more spending change on education. The status of rural, minority and poor counties, as expected, has no effect on how funding equity changed over the $2000-06$ period.

Some major taxes are shared between central, provincial and local governments in China. The central government determines the ratio of shares between central and provincial governments and each provincial government determines the ratio of shares between it and local governments. We calculate the rate of tax shares by provincial governments (relative to local governments) to examine the link between tax sharing and education funding equity. The VAT and personal income tax shared by provincial governments show positive impact, while business tax and corporate income tax are negative. Note that a large provincial tax share indicates less local fiscal capacity, thus the increased share of VAT and personal income tax increases inequity, while the increased business tax and corporate income tax may dampen the incentive for economic development accompanied with less inequity.

\section{Conclusion}

Against a background of high economic growth and rapid sociopolitical development in the past three decades, education finance in China has transitioned from a local government-administered regime to one that is a combination of local, provincial and central government funding. Beginning in 2000, the central and provincial governments have stepped in to try to drastically reduce interregional disparity within and across provinces and to improve equity and the overall quality of basic education throughout China's vast rural areas. The fast-tracked transition provides a good window for scholars to investigate the impacts of external policy shocks on education finance. In this chapter, we have attempted to test the effects of the Chinese Government's new funding scheme on the 
intraprovincial equity of education funding. With a constructed inequity index, we have examined the impact of policy shocks, controlling for multiple factors.

The regression results indicate that the key independent variable, education expenditure decreases funding equity, probably because education expenditure is a function of local wealth-that is, localities with high concentrations of wealth tend to invest more heavily in education, whereas poor regions cannot. Among government finance variables, most of the revenue sources seem to work towards increasing inequity (the index), thus decreasing funding equity. On the policy side, since total fiscal transfer is an aggregate measure that includes tax returns, which, to a large extent, captures the level of local economic development, it seems that total fiscal transfers decrease education finance equity, while discretionary transfers and special-purpose transfers are not significant. However, after taking out the basic level of transfers, including tax rebates, changes in both discretionary and special transfers become very significant and negative, indicating they are indeed helpful in increasing equity (or at least in dampening increases in inequity). The policy target of the change in fiscal transfer payments is therefore helping local governments to improve public services such as basic education. Coefficients on the year effects indicate that the macro policy became more effective over the sample period, improving the funding equity of education. Nevertheless, the changes in transfers are relatively small compared with the primary funds for education, limiting their dampening impact on the large and growing disparity. The inequity index trended continuously upwards from 2001 to 2006. Under the current education finance regime, the issue of equity in education funding across counties (even within provinces) still has a long way to go to be resolved and deserves more policy attention.

In summary, since the inequity index is highly related to local fiscal capacity, two conclusions can be drawn based on the results. First, almost all variables related to the local economy-wealthy or poor-show a significant effect on funding equity. Second, variables that increase the wealth of rich counties drag down their equity, while those increasing the wealth of poor counties increase their equity-both converging to the mean. Therefore, our results do not show evidence of improved equity from the new financing scheme and policies, and the disparity is still obvious between developed and less-developed counties. Given the rapidly growing economy during the period of analysis, there is a significant increase in intergovernmental transfers. These transfers may be helpful in 
decreasing interprovincial disparities; however, in relation to our focus on intraprovincial inequity, the transfers are not very effective in decreasing intraprovincial inequity of education funding. The results, however, are still preliminary, with limitations on the data range and lack of rigorous analysis of causal relationships. Further exploration and improvements in the reliability of estimates should be conducted in future research.

\section{References}

Andrews, M., W. Duncombe and J. Yinger. 2002. 'Revisiting economies of size in American education: Are we any closer to a consensus?' Economics of Education Review 21(3): 245-62. doi.org/10.1016/ S0272-7757(01)00006-1.

Baicker, K. and N. Gordon. 2006. 'The effect of state education finance reform on total local resources'. Journal of Public Economics 90(8-9): 1519-35. doi.org/10.1016/j.jpubeco.2006.01.003.

Berne, R. and L. Stiefel. 1994. 'Measuring equity at the school level: The finance perspective'. Educational Evaluation and Policy Analysis 16(4): 405-21. doi.org/10.3102/01623737016004405.

Besley, T. and S. Coate. 2003. 'Centralized versus decentralized provision of local public goods: A political economy approach'. Journal of Public Economics 87(12): 2611-37. doi.org/10.1016/S0047-2727 (02)00141-X.

Duncombe, W. and J. Yinger. 1998. 'School finance reform: Aid formulas and equity objectives'. National Tax Journal 51(2): 239-62.

Hou, Y., Z. Bu and Y. Wang. 2010. 'Central financing, sub-central redistribution, and funding adequacy in heterogeneous localities: Evidence from China's recent reform'. 26 April. Available from: ssrn. com/abstract=1596289 (accessed 19 July 2017). doi.org/10.2139/ ssrn.1596289.

Liu, F. 2005. 'Education equity under market economy: Problems and institutional arrangement'. Journal of Beijing Normal University (Social Science Edition) 187(1). 
Murray, S., W. Evans and R. Schwab. 1998. 'Education finance reform and the distribution of education resources'. American Economic Review 88(4): 789-812.

Qin, W. and Y. Li. 1992. Decision Making in Education Input. Beijing: Peking University Press.

Rubenstein, R., S. Ballal, L. Stiefel and A. E. Schwartz. 2008. 'Equity and accountability: The impact of state accountability systems on school finance'. Public Budgeting \& Finance 28(3): 1-22. doi.org/10.1111/ j.1540-5850.2008.00908.x.

Tsang, M. 1996. 'Financial reform of basic education in China'. Economics of Education Review 15(4): 423-44. doi.org/10.1016/S0272-7757 (96)00016-7.

Wang, R. 2001. Region differentials in China's education funding: A preliminary report on poverty relief. Beijing: Ministry of Education. Available from: en.moe.gov.cn/ (accessed March 2010).

Wang, R. 2004. 'County government educational budgeting in China: A case study'. Peking University Education Review (2).

Wu, A. M. and W. Wang. 2013. 'Determinants of expenditure decentralization: Evidence from China'. World Development 46(2): 176-84. doi.org/10.1016/j.worlddev.2013.02.004.

Yang, D. 2006. 'From equality of right to equality of opportunity: The slot of educational equity in new China'. Peking University Education Review (2).

Zeng, M. and Y. Ding. 2003. 'Education fiscal transfer and financial challenges for China's compulsory education'. Peking University Education Review 1(1): 84-94.

Zeng, M. and Y. Ding. 2005. 'A study of resource use and imbalanced allocation in China's compulsory education'. Education and Economy 2: 34-40.

Zhang, X., S. Fan, L. Zhang and J. Huang. 2004. 'Local governance and public goods provision in rural China'. Journal of Public Economics 88(12): 2857-71. doi.org/10.1016/j.jpubeco.2003.07.004. 
This text is taken from Value for Money: Budget and financial management reform in the People's Republic of China, Taiwan and Australia, edited by Andrew Podger, Tsai-tsu Su, John Wanna, Hon S. Chan and Meili Niu, published 2018 by ANU Press, The Australian National University, Canberra, Australia. 